\title{
Use of a Tobacco Agar Medium (TAM) to Detect Cryptococcus and Candida Colonies Isolated from Tobacco*
}

\author{
by \\ A. Morin and J. Joly \\ Imperial Tobacco Canada Limited, Montreal, Quebec, H4C 3P6, Canada
}

\section{SUMMARY}

The use of a tobacco agar medium (TAM) was investigated to visually differentiate Cryptococcus species from Rhodotorula and Candida species that can be isolated from tobacco. This study was first conducted with pure isolates of each of the major yeast species that have been isolated from tobacco. All Cryptococcus strains that were tested produced colonies with different degrees of pigmentation ranging from light to dark brown or black. All Candida and Pichia colonies were white to off-white. Candida parapsilosis colonies were easily differentiated since they had rough contours and surfaces. All Rhodotorula colonies were pink or orange. In order to validate the use of this medium, tobacco was spiked with a mixed culture of Cryptococcus, Candida, Rhodotorula and Pichia. TAM allowed visual detection and enumeration of the four yeast genera based on colony colour and/or morphology. [Beitr. Tabakforsch. Int. 22 (2006) 204-207]

\section{ZUSAMMENFASSUNG}

Die Verwendbarkeit eines Tabak-Agarnährbodens (TAM) zur visuellen Differenzierung der verschiedenen Cryptococcus-Arten von den Rhodotorula- und Candida-Arten, die man aus Tabak isolieren kann, wurde geprüft. Diese Untersuchung wurde zunächst mit reinen Isolaten der wichtigsten Hefearten, die aus Tabak isoliert wurden, durchgeführt. Alle untersuchten Cryptococcus-Stränge bildeten Kolonien von unterschiedlicher Pigmentierung, die von hellbraun bis dunkelbraun oder schwarz reichten. Alle Candida und Pichia-Kolonien waren weiß bzw. creme- farben. Kolonien von Candida parapsilosis waren aufgrund ihrer rauhen Konturen und Oberflächen leicht zu erkennen. Alle Rhodotorula-Kolonien waren rosa oder orangefarben. Um die Anwendung dieses Mediums beurteilen zu können, wurde Tabak mit einer Mischkultur aus Cryptococcus, Candida, Rhodotorula and Pichia versetzt. Der TAMNährboden erlaubte auf der Basis der Farbe und/oder Morphologie der Kolonien visuelles Erkennen und Auszählung der vier Hefearten. [Beitr. Tabakforsch. Int. 22 (2006) 204-207]

\section{RESUME}

L'utilisation d'un milieu gélosé à base de tabac (TAM) a été étudiée dans le but de différencier visuellement les espèces Cryptococcus des espèces Rhodotorula et Candida qui peuvent être isolées du tabac. Cette étude a d'abord été menée avec des isolats purs de chaque espèce de levures principalement isolées du tabac. Toutes les souches de Cryptococcus testées produisaient des colonies ayant différents degrés de pigmentation allant de brun pâle à brun foncé ou noir. Toutes les colonies de Candida et Pichia étaient dans les tons de blanc. Les colonies de Candida parapsilosis étaient facilement différenciées par leur contours et surfaces rugueux. Toutes les colonies de Rhodotorula étaient roses ou oranges. Afin de valider l'utilisation de ce milieu, le tabac a été enrichi d'une culture mixte de Cryptococcus, Candida, Rhodotorula et Pichia. Le milieu TAM a permis une détection et un décompte des quatre genres de levures en se basant sur la couleur et/ou la morphologie des colonies. [Beitr. Tabakforsch. Int. 22 (2006) 204-207] 


\section{INTRODUCTION}

A tobacco agar medium (TAM) supporting the growth of Cryptococcus neoformans and allowing its fast differentiation by formation of brown coloured colonies was recently described (8). The property of producing brown colonies on this media provided a definitive identification of Cryptococcus neoformans. It was attributed to the production of a black pigment from various substrates (caffeic acid, L-dopa, chlorogenic acid, dopamine, epinephrine, norepinephrine) which accumulated in the fungal cell due to laccase activity. $C$. neoformans has not been isolated from tobacco but other Cryptococcus considered as saprophytic species (e.g. C. albidus, C. diffluens, $C$. magnus) were isolated. Some of these Cryptococcus species can also produce laccase (2). Positive laccase activity was also recently reported in Candida species (6). The objective of this work was to validate the use of TAM to visually detect brown Cryptococcus colonies from other yeast species isolated from tobacco (e.g. Candida parapsilosis).

\section{MATERIALS AND METHODS}

\section{Preparation of media and yeast strains}

Tobacco Agar Medium (TAM): One litre distilled water was added to $50 \mathrm{~g}$ of flue-cured cut tobacco. The mixture was boiled for $30 \mathrm{~min}$, filtered through cheese cloth and its volume was then adjusted to one litre. Twenty grams of agar were added to this infusion which was then autoclaved at $121{ }^{\circ} \mathrm{C}$ for $15 \mathrm{~min}$. When TAM was used with antibiotic to inhibit bacterial growth, it was cooled at $45^{\circ} \mathrm{C}$ prior to supplementation with chloramphenicol $(100 \mu \mathrm{g} / \mathrm{mL})$, chlorotetracycline $(100 \mu \mathrm{g} / \mathrm{mL})$ and streptomycin $(30 \mu \mathrm{g} / \mathrm{mL})$. The agar was translucent and brownish yellow in colour after setting.

Littman Oxgall Agar (LOA) (Difco no. 0294): One litre distilled water was added to $55 \mathrm{~g}$ of LOA powder. The medium was autoclaved at $121{ }^{\circ} \mathrm{C}$ for $15 \mathrm{~min}$. The LOA was cooled at $45^{\circ} \mathrm{C}$ prior to supplementation with streptomycin $(30 \mu \mathrm{g} / \mathrm{mL})$.

Yeast Malt Agar (YMA)(Difco no. 0711): One litre distilled water was added to $21 \mathrm{~g}$ of YMA powder and $20 \mathrm{~g}$ of Bacto agar (Difco no. 0140). The medium was autoclaved at $121{ }^{\circ} \mathrm{C}$ for $15 \mathrm{~min}$. The YMA was cooled at $45^{\circ} \mathrm{C}$ prior to supplementation with chloramphenicol $(100 \mu \mathrm{g} / \mathrm{mL})$ and chlorotetracycline $(100 \mu \mathrm{g} / \mathrm{mL})$.

Microorganisms: Except for Candida albicans ATCC strain no. 10231, the Rhodotorula, Cryptococcus, Pichia and Candida species selected for this work were isolated from uncured and flue-cured tobacco on either LOA, or YMA or potato dextrose agar (PDA) (Table 1). They were maintained at $8{ }^{\circ} \mathrm{C}$ on PDA slant. Their identification was confirmed by using the Biolog YT microplate (Biolog Inc., Hayward, CA, USA). Prior to streaking on tobacco agar and other media, all yeasts were cultured and maintained on PDA at $26{ }^{\circ} \mathrm{C}$ for 72 h. Candida bombi strain L010, Pichia
Table 1. Colour of yeast colonies following incubation for ten days at room temperature $\left(20-26^{\circ} \mathrm{C}\right)$ on Tobacco Agar Medium (TAM) (non inoculated tobacco agar was translucent and brownish yellow in colour)

\begin{tabular}{|c|c|}
\hline Strain name & Colour and appearance of colony ${ }^{a}$ \\
\hline \multicolumn{2}{|c|}{ Candida albicans } \\
\hline L004-ATCC no. 10231 & $\mathrm{~W}$ to $\mathrm{OW}$ \\
\hline \multicolumn{2}{|c|}{ Candida parapsilosis } \\
\hline L079 & Ww to $O W w$ \\
\hline L089 & Ww to OWw \\
\hline L094 & Ww to Oww \\
\hline \multicolumn{2}{|c|}{ Cryptococcus } \\
\hline L072 C. diffluens & LB to $B$ \\
\hline L092 C. albidus & LB to $B$ \\
\hline L099 C. oeirensis & $\mathrm{LB}$ to $\mathrm{BL}$ \\
\hline L103 C. diffluens & $\mathrm{LB}$ to $\mathrm{BL}$ \\
\hline L104 C. liquefaciens & LB to $B$ \\
\hline L108 C. magnus & $\mathrm{LB}$ to $\mathrm{BL}$ \\
\hline L119 C. albidus & LB to $B$ \\
\hline \multicolumn{2}{|c|}{ Rhodotorula } \\
\hline L083 R. mucilaginosa & $P$ \\
\hline L087 R. mucilaginosa & $\mathrm{P}$ \\
\hline L111 R. minuta & OWo to OB \\
\hline L112 R. minuta & $\mathrm{P}$ \\
\hline L113 R. mucilaginosa & $P$ \\
\hline L117 R. slooffiae & $\mathrm{O}$ \\
\hline \multicolumn{2}{|r|}{ Others } \\
\hline L010 Candida bombi & $\mathrm{W}$ to $\mathrm{OW}$ \\
\hline L015 Pichia subpelliculosa & W \\
\hline
\end{tabular}

\footnotetext{
${ }^{\mathrm{a}} \mathrm{w}=$ wrinkled; $\mathrm{W}=$ white $; \mathrm{OW}=$ off-white; $\mathrm{OWo}=$ off-white orange; $\mathrm{BL}=$ black; $\mathrm{B}=$ brown; $\mathrm{LB}=$ light brown; $\mathrm{O}=$ orange; $\mathrm{OB}$ = orange brownish; $\mathrm{P}=$ pink.
}

subpelliculosa strain L015 and Candida albicans strain ATCC no. 10231 were used as negative controls because their colonies were white to off white after ten days of incubation.

\section{Preparation of spiking yeast suspensions}

Candida parapsilosis (L094), Cryptococcus albidus (L092), Rhodotorula mucilaginosa (L113) and Pichia subpelliculosa (L015) were grown on PDA for $48 \mathrm{~h}$ at $26{ }^{\circ} \mathrm{C}$. Ten $\mathrm{mL}$ of yeast suspensions in 1X Ringer solution were prepared in a Biolog turbidimeter $(590 \mathrm{~nm})$ and adjusted to $32 \% \pm 2 \%$ transmittance. Decimal dilutions $(1: 10 \mathrm{v} / \mathrm{v})$ of each of these suspensions in 1X Ringer solution were prepared. A $0.5 \mathrm{~mL}$ portion of each dilution was delivered either onto TAM supplemented (TAMS) or not with antibiotics, or onto LOA or into YMA. For TAM and LOA, the diluted sample was surface spread and for YMA the pour plate method was used. The plates were incubated for ten days at room temperature (20-26 $\left.{ }^{\circ} \mathrm{C}\right)$. Yeast counts were expressed in $\mathrm{CFU} / \mathrm{mL}$ and transformed in $\log$ of $\mathrm{CFU} / \mathrm{mL}$.

\section{Preparation of non inoculated control tobacco samples}

An aliquot of $20 \mathrm{~g}$ of flue-cured cut tobacco was placed in a $19 \times 30 \mathrm{~cm}$ stomacher bag (Nasco Whirl-Pak filter bags Cat No. B01318) containing $250 \mathrm{~mL}$ of $1 \mathrm{X}$ Ringer solution. The 

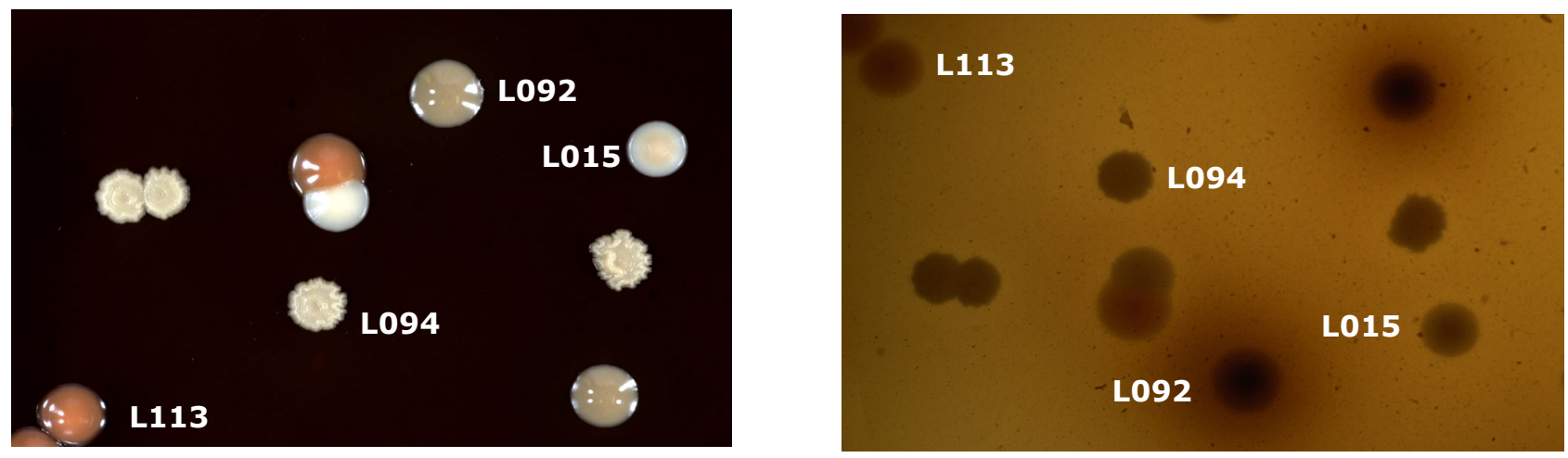

Figure 1. Yeasts grown for ten days on TAM at room temperature $\left(20-26{ }^{\circ} \mathrm{C}\right)$ (L015 : Pichia subpelliculosa; L092 : Cryptococcus albidus; L094 : Candida parapsilosis; L113 : Rhodotorula mucilaginosa )

bag was agitated at room temperature for $10 \mathrm{~min}$ in a Lab Blender Stomacher Model 400 (Seward Lab., London, SEI 9UG, UK). Four-fold dilutions (5/15 v/v) ranging from $1 / 4$ to $1 / 16$ were prepared using $1 \mathrm{X}$ Ringer solution. A $0.5 \mathrm{~mL}$ portion of the primary macerate and the prepared dilutions were delivered onto TAM, or onto LOA, into YMA in triplicate and onto TAMs in duplicate. The plates were incubated for ten days at room temperature $\left(20-26^{\circ} \mathrm{C}\right)$.

\section{Preparation of spiked tobacco samples}

A $0.75 \mathrm{~mL}$ portion of each yeast cell suspension were added to the stomacher bag containing the non inoculated control tobacco samples and agitated for $1 \mathrm{~min}$. Dilutions up to $1 / 1024$ and inoculations were performed as per control tobacco. The plates were incubated for ten days at room temperature $\left(20-26^{\circ} \mathrm{C}\right)$. Yeast counts were expressed as $\mathrm{CFU} / \mathrm{mL}$ and transformed into $\log$ of $\mathrm{CFU} / \mathrm{mL}$.

\section{RESULTS}

Initially, the TAM was translucent and brownish yellow in colour. Following growth of all yeast strains, it became dark brown, except Candida bombi which did not darken the media. All Cryptococcus strains produced colonies with different degrees of pigmentation from light brown to brown or black. A dark brown halo was also visible around all Cryptococcus colonies on the reverse of the plate. All Candida and Pichia colonies were white to off-white and all Rhodotorula were pink or orange (Table 1). Candida parapsilosis colonies were easily differentiated from other Candida species since they had rough contours and surfaces at $20-26{ }^{\circ} \mathrm{C}$ (Figure 1).

No yeasts were detected in the control tobacco (Table 2). Yeast suspensions containing about $10^{7} \mathrm{CFU} / \mathrm{mL}$ were used to spike the flue-cured cut tobacco sample. Yeast counts of the order of $10^{7} \mathrm{CFU} / \mathrm{mL}$ were observed in spiked tobacco samples. The TAM supplemented or not with antibiotics, delivered yeast counts similar to the ones found in other media currently used to isolate and enumerate yeast (Table
2). The $\mathrm{pH}$ value of TAM was $5.0 \pm 0.02$ which rendered this medium selective enough to avoid using antibiotics to eliminate bacterial growth. The TAM did not inhibit mould growth.

\section{DISCUSSION}

This study was first conducted with pure isolates of each yeast genus predominantly isolated from tobacco, namely Rhodotorula, Candida and Cryptococcus species. Because the development of some Cryptococcus and Candida species could be harmful $(2,3,4,5,6,7)$, detection of Cryptococcus and Candida was investigated by using a tobacco agar medium(TAM). The yeast species were clearly differentiated following growth on TAM. The various degree of pigmentation of Cryptococcus strains has been proposed to divide the strains into four groups: true pigment, dark brown pigment, intermediate tonality and light pigment (1). We did not apply the above grouping because the pigmentation of Cryptococcus colonies was obviously different from the other genera tested i.e. Candida and Pichia (white to offwhite) and Rhodotorula (pink or orange).

In order to validate the use of TAM to detect brown Cryptococcus colonies from other yeast species, a simulation of tobacco inoculated with mixed suspensions of Candida, Cryptococcus, Pichia and Rhodotorula was investigated. Detection of these yeasts on TAM supplemented or not with antibiotics and all yeast counts were comparable to the ones observed in culture media currently used for fungal growth, namely LOA and YMA. The addition of antibiotics to TAM was not essential because bacterial growth was inhibited most likely by selective $\mathrm{pH}$ values of $5.0 \pm 0.02$.

In conclusion, tobacco agar can be used to visually distinguish Rhodotorula and Candida genus from Cryptococcus species. Candida parapsilosis can be differentiated from other Candida species based on colony morphology. Yeast strains isolated on this medium can be re-grown and further purified on Potato Dextrose Agar (PDA), a recommended general purpose medium used for cultivating yeasts. 
Table 2. Colour and appearance of yeast colonies and estimation of yeast spiking suspensions and in control tobacco on various media after ten days of incubation at room temperature $\left(20-26{ }^{\circ} \mathrm{C}\right)$

\begin{tabular}{|c|c|c|c|c|c|c|}
\hline \multirow[b]{2}{*}{ Media } & \multirow[b]{2}{*}{ Strain name ${ }^{a}$} & \multirow[b]{2}{*}{ Colour and appearance of the colony } & \multicolumn{4}{|c|}{ Yeast - Log of CFU/mL } \\
\hline & & & TAMs $^{\text {b }}$ & TAM & LOA & YMA \\
\hline \multirow{2}{*}{\multicolumn{3}{|c|}{ Control : Flue-cured cut tobacco (non inoculated) }} & not detecte & not detected & not detected & not detected \\
\hline & & & $\begin{array}{l}\text { Yeas } \\
\text { (Log } \\
\text { bef }\end{array}$ & $\begin{array}{l}\text { pension } \\
\text { FU/mL) } \\
\text { oiking }\end{array}$ & $\begin{array}{l}\text { Yeast } \\
\text { (Log of } \\
\text { after }\end{array}$ & $\begin{array}{l}\text { covery } \\
\text { FU/mL) } \\
\text { iking }\end{array}$ \\
\hline \multirow[t]{4}{*}{ TAMs } & L094 & White to off white wrinkled & & & & \\
\hline & L092 & Light brown to brown & & & & \\
\hline & L113 & Pink & & & & \\
\hline & L015 & White & & & & \\
\hline \multirow[t]{4}{*}{ TAM } & L094 & White to off white wrinkled & & & & \\
\hline & L092 & Light brown to brown & & & & \\
\hline & L113 & Pink & & & & \\
\hline & L015 & White & & & & \\
\hline \multirow[t]{3}{*}{ LOA } & $\begin{array}{l}\text { L094 } \\
\text { L015 }\end{array}$ & Blue & & & & \\
\hline & L092 & Light grey & & & & \\
\hline & L113 & Orange & & & & \\
\hline \multirow[t]{2}{*}{ YMA } & $\begin{array}{l}\text { L094 } \\
\text { L092 } \\
\text { L015 }\end{array}$ & White & & & & \\
\hline & L113 & Orange & & & & \\
\hline
\end{tabular}

a Strain name: L094 : Candida parapsilosis; L092 : Cryptococcus albidus; L113 : Rhodotorula mucilaginosa; L015 : Pichia subpelliculosa.

b TAMs: TAM supplemented with antibiotics.

\section{REFERENCES}

1. Hernandez Idel C., G.M. Machin, C.M. Andreu, and M.T. Zaragozi: Pigmentation of strains from Cryptococcus neoformans on sunflower seed agar; Rev Cubana Med Trop. 55 (2003) 119-120.

2. Ikeda, R., T. Sugita, E.S. Jacobson, and T. Shinoda: Laccase and melanization in clinically important Cryptococcus species other than Cryptococcus neoformans; J. Clin. Microbiol. 40 (2002) 1214-1218.

3. Kordossis, T., A. Avlami, A. Velegraki, I. Stefanou, G. Georgakopoulos, C. Papalambrou, and N.J. Legakis: First report of Cryptococcus laurentii meningitis and a fatal case of Cryptococcus albidus cryptococcaemia in AIDS patients; Med. Mycol. 36 (1998) 335-339.

4. Loison, J., J.P. Bouchara, E. Guého, L. de Gentile, B. Cimon, J.M. Chennebault, and D. Chabasse: First report of Cryptococcus albidus septicaemia in an HIV patient; J. Infect. 33 (1996) 139-140.

5. Melo, J.C., S. Srinivasan, M.L. Scott, and M.J. Raff: Cryptococcus albidus meningitis; J. Infect. 2 (1980) 79-82.
6. Morris-Jones, R., B.L. Gomez, S. Diez, M. Uran, S.D. Morris-Jones, A. Casadevall, J.D. Nosanchuk, and A.J. Hamilton: Synthesis of melanin pigment by Candida albicans in vitro and during infection; Infect. Immun. 73 (2005) 6147-6150.

7. Tainwala, S.: A study of prevalence of serotypes and variants of Cryptococcus neoformans in cerebrospinal fluid; MD Dissertation. University of Mumbai, 2002.

8. Tendolfar, U., S. Tainwala, S. Jog, and M. Mathur: Use of a new medium - Tobacco Agar, for pigment production of Cryptococcus neoformans; Ind. J. Med. Microbiol. 21 (2003) 277-279.

Address for correspondence:

André Morin

Imperial Tobacco Canada Ltd

3711 St. Antoine

Montreal, QC, H4C3P6

Canada

E-mail:amorin@itl.ca 